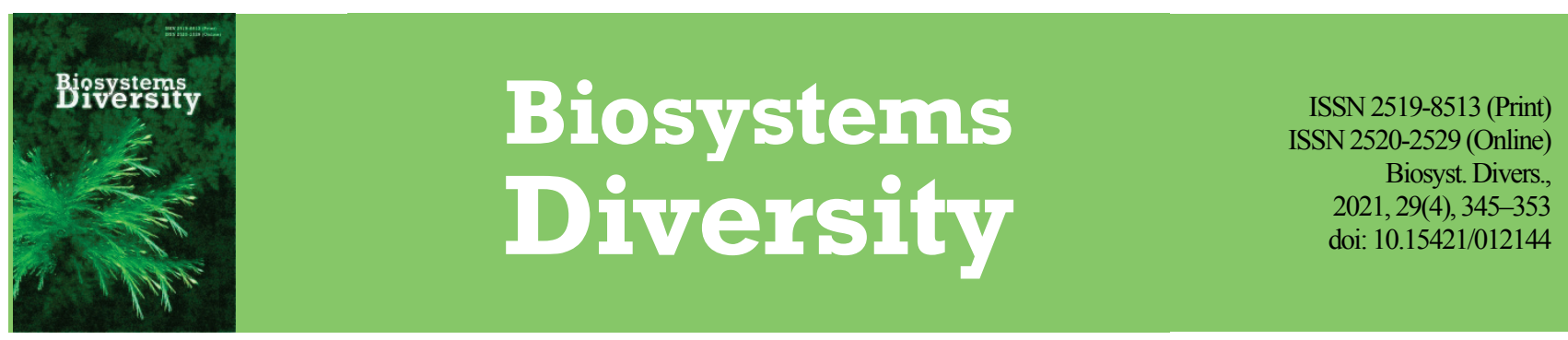

\title{
Fouling communities of microscopic fungi on various substrates of the Black Sea
}

\author{
N. I. Kopytina, E. A. Bocharova \\ A. O. Kovalevsky Institute of Biology of the Southern Seas of RAS, Moscow, Russia
}

Article info

Received 01.10.2021

Received in revised form 25.10.2021

Accepted 27.10.2021

A. O. Kovalevsky Institute of Biology of the Southern Seas of Russian Academy of Sciences, Leninsky pr., 38, bldg. 3, 12/2, Moscow 119991, Russia.

Tel.: +7-978-836-36-56.

E-mail:

eabocharovainbum@, gmail.com

\author{
Kopytina, N. I., \& Bocharova, E. A. (2021). Fouling communities of microscopic fungi on various substrates of the Black Sea. Biosys- \\ tems Diversity, 29(4), 345-353. doi:10.15421/012144
}

Fungi are the most active biodeteriorators of natural and man-made materials. The article presents generalizations of the studies (20012019) of communities of microscopic fungi within biofilms on various substrates: shells of live Mytilus (Mytilus galloprovincialis, 670 specimens) and Ostreidae (Crassostrea gigas, 90 specimens), fragments of driftwood (over 7,000), stones (40), concrete of hydrotechnical constructions along the shoreline (80) and wood between concrete blocks in constructions on the shores (80). The studies were carried out in Odessa Oblast, the coastal zone of Sevastopol and open area of the Black Sea. There were identified 123 species of micromycetes, belonging to 65 genera, 33 families, 21 orders, 10 classes, 4 divisions, 2 kingdoms: Fungi and Chromista (fungi-like organisms). The Chromista kingdom was represented by 1 species - Ostracoblabe implexa, on shells of $C$. gigas. The number of species of micromycetes on various substrates varied 23 (wood between concrete blocks of hydrotechnical constructions) to 74 (shells of M. galloprovincialis at the depths of 3 and $6 \mathrm{~m}$ ). On all the substrates, the following species were found; Alternaria alternata, Botryotrichum murorum. The communities were found to contain pathogenic fungi Aspergillus fumigatus (shells of mollusks, stones, concrete), A. terreus (concrete), Fusarium oxysporum, Pseudallescheria boydii (shells of mollusks). The best representation was seen for the Pleosporales order - from $12.9 \%$ (shells of M. galloprovincialis, $0.3 \mathrm{~m}$ depth) to $33.3 \%$ (shells of C. gigas) of the species composition. Toxin-producing species of Microascales in mycological communities accounted for $1.6 \%$ (driftwood) to $40.0 \%$ (concrete), and were also observed on shells of Bivalvia - 11.1-32.3\%. Similarity of species composition of mycological communities according to Bray-Curtis coefficient varied 21.1\% (driftwood and concrete, 10 shared species) to $72.7 \%$ (shells of $M$. galloprovincialis, the depths of 3 and $7 \mathrm{~m}$ and shells of $C$. gigas, 45 shared species). Using graphs of indices of mean taxonomic distinctness (AvTD, $\Delta^{+}$) and variation (Variation in Taxonomic Distinctness index, VarTD, $\Lambda+$ ), we determined deviations of taxonomic structure of the studied mycological communities from the level of mean expected values, calculated based on the list of species, taking into account their systematic positions. The lowest values of index $\Delta+$ were determined for communities on shells of M. galloprovincialis, $0.3 \mathrm{~m}$ depth, driftwood, stones and concrete. These communities had uneven distribution of species according to higher taxonomic ranks and minimum number of the highest taxa: 4-6 classes, 1-2 divisions, Fungi kingdom. Disproportion in species composition with decrease in the number of the highest taxa occurred in extreme environmental conditions. Using index $\Lambda+$, we found that the most complex taxonomic structure of fungi communities has developed on concrete and shells of $C$. gigas. In mycological communities on those substrates, the number of species was low ( 25 and 46), but they belonged to 4-7 classes, 2-3 divisions, 1-2 kingdoms. To compare the structures of mycological communities that have developed in such substrates in biotopes sea, sea-land-air, land-air, we compiled a list of fungi based on the literature data, which, taking into account our data, comprised 445 species of 240 genera, 103 families, 51 orders, 15 classes, 5 divisions, 2 kingdoms. The analysis revealed that on substrates with similar chemical composition, in all the biotopes, the species of the same divisions dominated (genus and family may vary). Therefore, in the biotope land-air - Hypocreales, Pleosporales, Eurotiales (genera Acremonium, Fusarium, Alternaria, Aspergillus, Penicillium); sea - Pleosporales, Eurotiales, Microascales (Alternaria, Aspergillus, Penicillium, Corollospora); sea-land-air - Pleosporales, Microascales (Alternaria, Leptosphaeria, Aspergillus, Penicillium, Corollospora, Halosarpheia). Monitoring of species composition of myxomycetes is needed in farms that cultivate industrial objects, recreation sites, various buildings for prevention of mycotoxin intoxication and infestation by mycodermatoses and other diseases caused by opportunistic and pathogenic fungi.

Keywords: marine fungi; concrete; mollusks; stones; wood; the Black Sea.

\section{Introduction}

In the marine environment, a large number of species of mycromycetes has been found - inhabitants of land: water (Kopytina, 2020), benthic sediments (Bubnova et al., 2020), driftwood (Immaculatejeyasanta et al., 2012), on shells and internal organs of mollusks (Borzykh \& Zvereva 2012, 2015; Greco et al., 2017; Hudyakova et al., 2017), corals (Yarden, 2014; Gleason et al., 2017), sponges (Pivkin et al., 2006), algae (Gnavi et al., 2017) and other marine organisms (Raghukumar, 2012; Gebruk et al., 2019). Some terrestrial fungi cause diseases of hydrobionts, for instance, Aspergillus sydowii (Bainier \& Sartory) Thom \& Church caused epizooty of marine sea fans (Gorgonia ventalina Linnaeus, 1758 and G. flabellum Linnaeus, 1758) in the Caribbean Sea (Alker et al., 2001; Gleason et al., 2017), the species was also isolated from shells of Mytilus (Mytilus galloprovincialis (Lamark, 1819)) in the Port of Genoa (Italy) (Greco et al., 2017). The pattern of interactions of organisms in fungi- hydrobionts associations has not been yet studied completely. Modern phylogenetic studies confirm that many obligate marine fungi have terrestrial origins, and introduction of micromycetes into marine environment has occured multiple times (Richards et al., 2012; Amend et al., 2019; Jones et al., 2019). Molecular-phylogenetic data obtained for marine fungi indicate their great similarity to terrestrial fungi such as Aspergillus sydowii, A. fumigatus, Penicillium verruculosum, $P$. chrysogenum, Pseudallescheria boydii, Epicoccum nigrum, Fusarium oxysporum, Metschnikoia zobellii, Candida akabanensis and some others (Richards et al., 2012; Jones et al., 2015, 2019). In the study by Jones et al. (2019), the list of species of marine fungi contains 1,255 species. The list includes terrestrial species isolated from marine environment, the genome of which was confirmed by molecular studies. A total of 38 representatives of Aspergillus and Penicillium was confirmed in such a way. Currently, there are relatively few molecular studies of fungi in the marine environment, but using this method enlarges the possibilities of finding a greater number of 
species (Richards et al., 2012). The modern notion "marine fungi" was proposed by Pang et al. (2016): any fungus that was isolated from marine locations several times and was able to grow or develop spores on various substrates; create symbioses with other organisms; have confirmed adaptation, development or metabolic activity in the marine environment at genetic level. Fungi play an important role in decomposition of lignin and cellulose in the marine environment, as indicated by the large amount of fungi on driftwood and mangrove trees (Kohlmeyer \& Kohlmeyer, 1979; Nambiar \& Raveendran, 2008; Tamayo-Cevallos, 2020; Tibell et al., 2020). Cellulose-decomposing fungi mostly belong to Halosphaeriaceae family and are considered obligate marine species.

Marine endolithic fungi (living inside rocks) destruct limestone structures of hydrobionts: shells of mollusks, Balanus, Foraminifera, corals, limestone passages of Cossidae. Mycological communities that grow on animals include marine and terrestrial species (Kohlmeyer, 1969; Ananda \& Prasannarai, 1998; Kopytina \& Lebedovskaya, 2014; Yarden, 2014).

Fungi take part in destruction of natural stones and concrete constructions in sea and land. Due to the large-scale character of this problem, there has been formed a specialized sphere of mycology - geomycology, which is related to the study of microbiota of natural and man-made stones, and also the role of fungi in geological processes. Destruction of stones and concrete first of all occurs under the influence of acids produced by fungi (Cwalina, 2008; Bindschedler et al., 2016). Fungi that were isolated from damaged stone substrates generated the following acids: oxalic acid, lactic, acetic, phosphate, glycerol, citric, gluconic, fumaric, malic and succinic, which was experimentally confirmed on strains of cultures of Aspergillus niger Tiegh. Ch 4/07, A. ustus (Bain.) Thom. 1/07, A. versicolor Tirab. 127, Cladosporium sphaerospermum Penz. 2/07, Fusarium oxysporum Schltdl. 3/07, Mucor heterosporum Wehmer. 4/07, Penicillium brevicompactum Dierckx 65/07, P. chrysogenum Thom 37/06, P. griseo-purpureum DierckxL2/1, P. olivaceum Biourg 66/07, P. olivino-viride Biourg 18, P. oxalicum Currie et Thom 15/02, P. raperi L6/8, P. spinulosum Thom 19/06, P. vitale Pidopl. et Bilai L5/1, Scopulariopsis brevicaulis (Sacc.) 5/07, Trichoderma viride Pers. 10/07 and Ulocladium chartarum Preuss 17/06 (Barinova et al., 2010).

On the other hand, scientists have come to a conclusion that micromycetes are the most promising organisms for production of self-healing concrete. Hyphae of filamentous fungi develop an interconnected threedimensional network - mycelium, which acts as a biological fiber, improving the physical-mechanical characteristics of bioconcrete (Martuscelli et al., 2020). Mycelium has a large specific surface area, and therefore actively colonizes the substrate (Menon et al., 2019). Self-healing concrete, obtained using the method of adding spores or mycelium of micromycetes, has two advantages: fungi settle a large amount of calcium carbonate $\left(\mathrm{CaCO}_{3}\right)$, therefore filling the cracks during a relatively short time period (Jin et al., 2018; Luo et al., 2018), and the concrete maintains selfhealing property for a long time (Menon et al., 2019). Species of fungi that have been considered promising are Purpureocillium lilacinum (Thom) Luangsa-ard, Houbraken, Hywel-Jones \& Samson and Chrysosporium spp. (Magan, 2007); Neurospora crassa Shear \& B. O. Dodge (Li et al., 2014); Pestalotiopsis sp. and Xepiculopsis graminea (Lib.) Nag Raj (Li et al., 2015); Trichoderma reesei E. G. Simmons (Luo et al., 2018); Aspergillus nidulans (Eidam) G. Winter (Menon et al., 2019). However, micromycetes should be selected taking into account safety for animals and people, therefore scientists suggest methods of genetic engineering for reducing pathogenic properties of promising strains of fungi (Menon et al., 2019; Elkhateeb et al., 2021).

The objectives of the study. We analyzed the structure of communities of fungi and determined their taxonomic specifics in the fouling films on various substrates in the Black Sea and compared the structures of mycological communities in biotopes sea, sea-land-air, land-air on similar or chemically close substrates, according to the list of species which was composed based on the literature data.

\section{Materials and methods}

Over the period of 2001-2019, we studied communities of microscopic fungi on various substrates: shells of live Mytilus (Mytilus galloprovincialis), shells of live true oysters (Crassostrea gigas (Thünberg,
1793)), driftwood, natural stones, concrete of hydrotechnical constructions and wood between the concrete blocks of hydrotechnical constructions on beaches of cities of Odesa and Sevastopol.

Samples of Mytilus were collected from the depths of $0.3,3$ and $7 \mathrm{~m}$ within the framework of GloBallast in August-December of 2001 on hydrotechnical constructions of the Port of Odesa, 670 specimens. Divers collected druses of Mytilus weighing 100-150 g into polyethylene bags. True oysters were taken from 4 in the farms of Crimea in 2012, 2017, 2019, 120 specimens in total. Two farms are located in Donuzlav Bay: one by the entrance to the bay, and the other in the area of Novoozernoe village. The third one was the mussel and oyster farm Ltc Scientific Research Marikultura in the water area adjacent to the laboratory building of the Federal Research Center of Institute of Biology of the Southern Seas of the Russian Academy of Sciences between the southern mole of the Sevastopol Bay and Karantynna Bay, the fourth - in the Kozacha Bay (Sevastopol). Average depth of dive at which the collectors found mollusks was 4.5-7.0 m, maximum immersion $-12 \mathrm{~m}$. The material was collected into new cellophane bags. The mollusks were transported to the laboratory in refrigerator bags, stored in freezing chamber in the temperature of $-18{ }^{\circ} \mathrm{C}$ before the inoculation. The shells were cleared from foulants, removed from the bodies, fragmented and rinsed with sterile marine water. To inhibit the growth of accompanying bacterial flora, the rinsed shells were submerged in sterile marine water with solution of antibiotics (penicillin -500 thou $\mathrm{U} / \mathrm{L}$ and streptomycin $-0.5 \mathrm{~g} / \mathrm{L}$ ). The shells were kept in the solution for $2 \mathrm{~h}$, then rinsed 3 times in sterile marine water and put on the surface of solid growth medium in Petri dishes (Borzykh \& Zvereva, 2014). To isolate fungi, we used sterile strips of filter paper and poplar sawdust, and also the following microbiological media: Czapek (manufactured by Ltc. Scientific Productive Center Biokompas-S, Uglich) and starvation agar, prepared on marine water (18 $\mathrm{g}$ of microbiological agar per $1 \mathrm{~L}$ of water). The media were sterilized in an autoclave under the pressure of $0.5 \mathrm{~atm}$., in the temperature of $112{ }^{\circ} \mathrm{C}$ for $30 \mathrm{~min}$. Before distribution in Petri dishes, into the media, cooled to approximately 40 $45^{\circ} \mathrm{C}$, solution of mixture of antibiotics was added in the same doses as when the shells were rinsed. Fungi were cultivated in thermostate in the temperature of $18-20^{\circ} \mathrm{C}$ for $10-15$ days).

In 2001-2019, fragments of decomposing wood with signs of being in the water (driftwood) were collected in the pseudolittoral zone of beaches of cities of Odesa and Sevastopol, limans of Odesa Oblast (Tylyhylsky, Malyi Adzhalyksky, Velykyi Adzhalyksky, Syhyi, Hadzhybeisky). In 2016-2017, during sailings No. 87, 95, 98, 101 of Scientific Research Vessel Professor Vodianytsky, fragments of wood were collected from the open area of the Black Sea (Fig. 1). Overall, over 7,000 specimens of wood were examined. From cellulose-containing substrates, the fungi were isolated using accumulation-growth completion technique. Fragments of wood were rinsed with tap water. The substrates were put into Petri dishes, perfused with sterile marine water, and cultivated for 2-12 months, periodically checking for fruit bodies and conidia on the substrates. The driftwood was incubated in a laboratory at room temperature and natural light (Kohlmeyer \& Kohlmeyer, 1979; Nambiar et al., 2008). When the wood is decomposing, change in the species composition of fungi occurs and therefore a longer cultivation period is needed to find la arge amount of species.

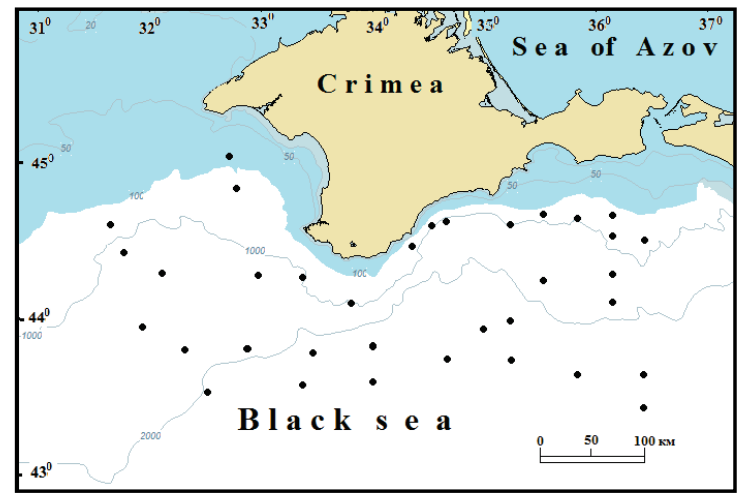

Fig. 1. Schematic map of the sampling points of fragments of driftwood in sailings No. 87, 95, 98, 101 (2016-2017) 
From a $10 \times 10 \mathrm{~cm}$ area ( 1 sample), using a metal putty knife, we scraped the overgrown material from stones and concrete traverses on the beaches. The sampling plots were no higher than $0.3 \mathrm{~m}$ above shore line, the fragments of attached wood between the concrete blocks of hydrotechnical constructions were removed by scalpel. We took 40 samples from stones, 80 from concrete, and 130 fragments of wood from cavities between the concrete blocks. From the scrapes from stones and concrete, the fungi were isolated to cellulose-containing substrates (strips of filter paper, sawdust of deciduous trees) in sterile marine water, and also on standard mycologic Czapek media and starvation agar. The material was cultivated in a thermostat in $18-20^{\circ} \mathrm{C}$ temperature or the room temperature for 2-8 weeks (on agar-containing media) 2-8 months (on cellulosecontaining substrates).

The fungi were identified according to morphologic-cultural features, using the works of Kohlmeyer \& Kohlmeyer (1979), Bilay \& Koval' (1988), De Hoog et al. (2000), Jones et al. (2009). Species names of micromycetes were checked according to the International Electronic Nomenclature Data Base Index Fungorum (www.indexfungorum.org).

The results were analyzed using statistical software pack Primer ${ }^{R}$ 5.2.8, Similarity function, Cluster, MDS, Taxdtest (Clarke \& Warwick, 2001; Clarke et al., 2014). Similarity of mycological communities according to species composition of fungi (presence/absence of species) was assessed as percentages using the Bray-Curtis coefficient. Diversity of mycological communities at the systematic level higher than species was given characteristic with the indices of mean taxonomical distinctness (Average Taxonomic Distinctness index, AvTD, $\Delta^{+}$) and variation (Variation in Taxonomic Distinctness index, VarTD, $\Lambda+$ ). Values of those indices do not depend on the number of samples, time of sampling and quantitative characteristics of organisms. The indices were calculated based on comparing two matrixes: a) list of species; b) list of species with each taxon identified to systematic levels - species, genus, order, class, division, kingdom, and may be presented as graphs. Graphs of indices resemble a funnel that narrows as the number of species increases. The dotted line in the center of the funnel reflects conditional mean values of indices, taking into account proportional distribution of species in subsequent taxonomic levels depending on the number of species. The probability funnel includes values of indices in $95 \%$ interval. Values of $\Delta^{+}$ index indicate proportions of distribution of taxa of lower link (species, genus and higher) in subsequent higher levels (vertical distribution). Index $\Lambda+$ reflects evenness of the number of low taxa in the levels higher than one (genera, families, orders, and other), horizontal distribution. Application of the indices allows assessment of the taxonomic structure of the communities, and also conclusion about whether the environmental conditions are favourable or unfavourable for the analyzed group of organisms (Clarke \& Warwick, 1998; Clarke \& Warwick, 2001).

\section{Results}

The study revealed 123 species of micromycetes, belonging to 65 genera, 33 families, 21 orders, 10 classes, 4 divisions, 2 kingdoms: Fungi and Chromista. The Chromista kingdom unites a large group of eukaryotes, including fungi-like organisms. The number of species of micromycetes on various substrates ranged from 23 (wood between the blocks of hydrotechnical constructions) to 74 (shells of mussels at the depths of 3 and $6 \mathrm{~m}$ ). On all the substrates, the following species were found: Alternaria alternata, Botryotrichum murorum (authors and year of description are given in Table 1). Most species of fungi (58.5\%) belong to orders Pleosporales, Microascales, Eurotiales of the Fungi kingdom. The Chromista kingdom in our studies was represented by 1 species - Ostracoblabe implexa.

Table 1

List of species of microscopic fungi found in the communities of overgrowths on various substrates in the Black sea

\begin{tabular}{|c|c|c|c|c|c|c|c|}
\hline Taxa & $\begin{array}{l}\text { Mytilus gallo- } \\
\text { provincialis } \\
(0.3 \mathrm{~m})\end{array}$ & $\begin{array}{l}\text { Mytilus gallo- } \\
\text { provincialis } \\
(3,7 \mathrm{~m})\end{array}$ & $\begin{array}{c}\text { Crassostrea } \\
\text { gigas } \\
(4-12 \mathrm{~m})\end{array}$ & $\begin{array}{l}\text { Wood and } \\
\text { driftwood }\end{array}$ & $\begin{array}{l}\text { Sto- } \\
\text { nes }\end{array}$ & $\begin{array}{l}\text { Con- } \\
\text { crete }\end{array}$ & $\begin{array}{c}\text { Wood between } \\
\text { concrete } \\
\text { blocks }\end{array}$ \\
\hline \multicolumn{8}{|c|}{ Fungi-Ascomycota } \\
\hline Acremoniun sp. & + & + & - & - & - & - & - \\
\hline zAlternaria alternata (Fr.) Keissl. & + & + & + & + & + & + & + \\
\hline A. avenicola E. G. Simmons, Kosiak \& Kwaśna & - & + & + & - & - & - & - \\
\hline A. brassicae (Berk.) Sacc. & - & + & + & - & - & - & - \\
\hline A. brassicicola (Schwein.) Wiltshire & - & + & + & - & - & - & - \\
\hline A. calendulae Ondřej & - & + & + & - & - & - & - \\
\hline A. cichorii Nattrass & - & - & + & - & + & + & - \\
\hline A. dauci (J. G. Kühn) J. W. Groves \& Skolko & - & + & + & - & - & - & - \\
\hline A. infectoria E. G. Simmons & - & + & + & - & - & - & - \\
\hline A. porri (Ellis) Cif. & - & - & - & + & - & - & - \\
\hline A. radicina Meier, Drechsler \& E. D. Eddy & - & + & + & - & - & - & - \\
\hline Alternaria spp. & + & + & + & + & + & + & + \\
\hline A. tenuissima (Kunze) Wiltshire & - & + & - & + & + & + & - \\
\hline Arthrinium sp. & - & + & + & - & - & - & - \\
\hline$\approx$ Aspergillus carneus Blochwitz & - & - & - & - & + & - & - \\
\hline As. clavatonanicus Bat., H. Maia \& Alecrim & - & + & + & - & + & + & - \\
\hline$\approx$ As. fumigatus Fresen. & + & + & + & - & + & + & - \\
\hline As. nidulans (Eidam) G. Winter & - & + & + & - & - & - & - \\
\hline$\approx$ As. niger Tiegh. & + & + & - & - & + & + & - \\
\hline$\approx$ As. sydowii (Bainier \& Sartory) Thom \& Church & - & + & + & - & - & - & - \\
\hline Aspergillus spp. & + & + & + & - & + & + & - \\
\hline$\approx^{p}$ As. terreus Thom & - & - & - & - & - & + & - \\
\hline Bipolaris sp. & - & + & + & - & - & - & - \\
\hline Bipolaris victoriae (F. Meehan \& H. C. Murphy) Shoemaker & - & - & - & - & + & - & - \\
\hline Botryomyces sp. & - & + & + & - & - & - & - \\
\hline Botryotrichum murorum (Corda) X. Wei Wang \& Samson & + & + & + & + & + & + & + \\
\hline $\begin{array}{l}\text { Candida dubliniensis D. J. Sullivan, Western., K. A. Haynes, } \\
\text { Dés. E. Benn. \& D. C. Coleman }\end{array}$ & + & + & - & - & - & - & - \\
\hline$\approx$ Carbosphaerella leptosphaerioides I. Schmidt & - & - & - & + & - & - & - \\
\hline$\approx$ Ceriosporopsis calyptrata Kohlm. & - & - & - & + & - & - & - \\
\hline$\approx C$. halima Linder & + & + & - & $H+$ & - & - & - \\
\hline Chaetomium cochliodes Palliser & + & + & + & - & - & - & - \\
\hline C. elongatum Czerepan. & - & - & - & + & - & - & - \\
\hline C. globosum Kunze & + & + & + & + & + & - & - \\
\hline Chaetomium sp. & - & + & + & + & + & + & - \\
\hline C. spinosum Chivers & + & + & - & - & - & - & - \\
\hline Cirrenalia basiminuta Raghuk. \& Zainal & + & + & - & + & - & - & + \\
\hline
\end{tabular}




\begin{tabular}{|c|c|c|c|c|c|c|c|}
\hline Taxa & $\begin{array}{l}\text { Mytilus gallo- } \\
\text { provincialis } \\
(0.3 \mathrm{~m})\end{array}$ & $\begin{array}{l}\text { Mytilus gallo- } \\
\text { provincialis } \\
(3,7 \mathrm{~m})\end{array}$ & $\begin{array}{l}\text { Crassostrea } \\
\text { gigas } \\
(4-12 \mathrm{~m}) \\
\end{array}$ & $\begin{array}{l}\text { Wood and } \\
\text { driftwood }\end{array}$ & $\begin{array}{l}\text { Sto- } \\
\text { nes }\end{array}$ & $\begin{array}{l}\text { Con- } \\
\text { crete }\end{array}$ & $\begin{array}{l}\text { Wood between } \\
\text { concrete } \\
\text { blocks }\end{array}$ \\
\hline C. macrocephala (Kohlm.) Meyers \& R. T. Moore & + & + & + & $+1+$ & - & - & + \\
\hline Cirrenalia sp. & + & + & - & + & - & - & - \\
\hline Cladosporium algarum Cooke \& Massee & - & - & - & + & + & - & - \\
\hline$\approx$ C. cladosporioides (Fresen.) G. A. de Vries & - & + & + & - & + & + & - \\
\hline C. herbarum (Pers.) Link & - & - & - & - & + & + & - \\
\hline Cladosporium sp. & - & + & + & + & - & - & + \\
\hline Clavatospora bulbosa (Anastasiou) Nakagiri \& Tubaki & - & - & - & + & - & - & - \\
\hline$\approx$ Corollospora intermedia E. B. G. Jones & - & - & - & + & - & - & - \\
\hline$\approx$ C. lacera (Linder) Kohlm. & - & - & - & + & - & - & - \\
\hline$\approx C$. maritima Werderm. & + & + & + & $H+$ & - & - & + \\
\hline$\approx$ C. pulchella Kohlm., I. Schmidt \& N. B. Nair & - & - & - & + & - & - & - \\
\hline$\approx$ C. trifurcata (Höhnk) Kohlm. & + & + & + & $H+$ & - & - & + \\
\hline Cumulospora marina I. Schmidt & - & + & - & + & - & - & - \\
\hline $\begin{array}{l}\text { Curvularia hawaïensis (Bugnic. ex M. B. Ellis) Manamgoda, L. Cai } \\
\text { \& K. D. Hyde }\end{array}$ & - & + & + & - & - & - & - \\
\hline Dictyosporium elegans Corda 1836 & - & - & - & + & - & - & - \\
\hline D. pelagicum (Linder) G. C. Hughes ex E. B. G. Jones & + & + & - & + & - & - & + \\
\hline Dictyosporium $\mathrm{sp}$. & + & + & - & + & - & - & - \\
\hline Diplodia orae-maris Linder & - & - & - & + & - & - & - \\
\hline Drechslera sp. & - & + & + & + & - & - & - \\
\hline Dryosphaera navigans Jørg. Koch \& E. B. G. Jones & - & - & - & + & - & - & - \\
\hline Emericellopsis maritima Beliakova & & & & + & & & \\
\hline Epicoccum nigrum Link & - & - & - & - & + & + & - \\
\hline Epicoccum sp. & - & + & + & - & + & - & - \\
\hline Fusarium graminearum Schwabe & - & + & + & - & - & - & - \\
\hline${ }^{p} F$. oxysporum Schltdl. & - & + & + & - & - & - & - \\
\hline Fusarium sp. & - & + & H & - & - & + & - \\
\hline Graphium sp. & + & + & - & + & - & - & - \\
\hline Halenospora varia (Anastasiou) E. B. G. Jones & - & + & - & + & + & - & + \\
\hline$\approx$ Haligena elaterophora Kohlm. & - & - & - & + & - & - & - \\
\hline$\approx$ Halosphaeria appendiculata Linder & - & - & - & + & - & - & - \\
\hline$\approx$ H. pileata (Kohlm.) Kohlm. & - & - & - & + & - & - & - \\
\hline zH. quadri-remis (Höhnk) Kohlm. & - & + & + & + & - & - & + \\
\hline $\begin{array}{l}\text { ₹Halosphaeriopsis mediosetigera (Cribb \& J. W. Cribb) T. W. John- } \\
\text { son (Trichocladium achrasporum (Meyers \& R. T. Moore) M. Dixon } \\
\text { ex Shearer \& J. L. Crane) }\end{array}$ & + & + & - & $+\mathrm{H}$ & - & - & + \\
\hline Humicola alopallonella Meyers \& R. T. Moore & + & - & - & + & - & - & + \\
\hline H. semispiralis (Udagawa \& Cain) X. Wei Wang \& Houbraken & - & + & - & - & - & - & - \\
\hline Humicola sp. & + & + & - & + & - & - & - \\
\hline ₹Juncigena adarca Kohlm., Volkm.-Kohlm. \& O. E. Erikss. & - & - & - & + & - & - & - \\
\hline $\begin{array}{l}\text { Juncigena fruticosae (Abdel-Wahab, Abdel-Aziz \& Nagah.) } \\
\text { A. N. Mill. \& Shearer }\end{array}$ & - & + & - & - & - & - & - \\
\hline Leptosphaeria albopunctata (Westend.) Sacc. & - & - & - & + & - & - & - \\
\hline Leptosphaeria orae-maris Linder & - & + & - & + & - & - & + \\
\hline Leptosphaeria sp. & - & - & - & + & - & - & - \\
\hline $\begin{array}{l}\text { Longicorpus striatisporus (K. D. Hyde) S. N. Zhang, K. D. Hyde \& } \\
\text { J. K. Liu }\end{array}$ & & & & + & & & \\
\hline Lulworthia sp. & - & - & - & + & - & - & - \\
\hline Microascus cinereus Curzi & + & + & - & - & - & - & - \\
\hline zMoleospora maritima Abdel-Wahab, Abdel-Aziz \& Nagah. & - & + & - & - & - & - & - \\
\hline Monodictys elegans Corda & - & - & - & + & - & - & - \\
\hline Monodictys pelagica (T. Johnson) E. B. G. Jones & + & + & + & + & - & - & + \\
\hline Monodictys sp. & - & - & - & + & + & - & + \\
\hline $\begin{array}{l}\text { ₹Moromyces varius (Chatmala \& Somrith.) Abdel-Wahab, } \\
\text { K. L. Pang, Nagah., Abdel-Aziz \& E. B. G. Jones }\end{array}$ & - & - & - & + & - & - & - \\
\hline$\approx$ Nais inornata Kohlm. & - & - & - & + & - & - & - \\
\hline $\begin{array}{l}\approx \text { Neomassariosphaeria typhicola (P. Karst.) Y. Zhang ter, J. Fourn. \& } \\
\text { K. D. Hyde }\end{array}$ & - & + & - & + & - & - & - \\
\hline Oncopodiella trigonella $($ Sacc.) Rifai & - & - & - & + & - & - & - \\
\hline$\approx$ Paradendryphiella arenariae (Nicot) Woudenb. \& Crous & - & - & - & + & - & + & - \\
\hline$\approx$ Paradendryphiella salina (G. K. Sutherl.) Woudenb. \& Crous & - & - & - & + & + & - & - \\
\hline Penicillium aurantiogriseum Dierckx & + & + & + & - & - & - & - \\
\hline$\approx P$. brevicompactum Dierckx & - & - & - & - & + & + & - \\
\hline$\approx P$. citrinum Thom & - & - & - & + & + & + & + \\
\hline$\approx P$. commune Thom & - & - & - & - & + & + & - \\
\hline P. decumbens Thom & - & - & - & - & - & + & - \\
\hline P. exspansum Link & + & + & + & - & + & - & - \\
\hline Penicillium spp. & - & + & + & - & + & + & + \\
\hline Periconia prolifica Anastasiou & - & + & - & + & - & - & - \\
\hline Phoma sp. & - & + & - & + & - & - & + \\
\hline Pleospora sp. & - & - & - & + & - & - & + \\
\hline Preussia longisporopsis (S. I. Ahmed \& Cain) Kruys & - & + & - & - & - & - & - \\
\hline $\begin{array}{l}\text { Pseudallescheria boydii (Shear) McGinnis, A. A. Padhye \& Ajello } \\
\text { (Scedosporium apiospermum Sacc. ex Castell. \& Chalm.) }\end{array}$ & + & + & + & - & - & - & - \\
\hline Pseudeurotium ovale Stolk & + & + & - & - & - & - & - \\
\hline
\end{tabular}




\begin{tabular}{|c|c|c|c|c|c|c|c|}
\hline Taxa & $\begin{array}{c}\text { Mytilus gallo- } \\
\text { provincialis } \\
(0.3 \mathrm{~m}) \\
\end{array}$ & $\begin{array}{c}\text { Mytilus gallo- } \\
\text { provincialis } \\
(3,7 \mathrm{~m})\end{array}$ & $\begin{array}{c}\text { Crassostrea } \\
\text { gigas } \\
(4-12 \mathrm{~m}) \\
\end{array}$ & $\begin{array}{l}\text { Wood and } \\
\text { driftwood }\end{array}$ & $\begin{array}{l}\text { Sto- } \\
\text { nes }\end{array}$ & $\begin{array}{l}\text { Con- } \\
\text { crete }\end{array}$ & $\begin{array}{c}\text { Wood between } \\
\text { concrete } \\
\text { blocks }\end{array}$ \\
\hline Remispora maritima Linder & - & - & - & + & - & - & + \\
\hline$\approx$ Savoryella lignicola $\mathrm{E}$. B. G. Jones \& R. A. Eaton & + & + & - & + & - & - & - \\
\hline $\begin{array}{l}\text { ₹Sammeyersia grandispora (Meyers) S. Y. Guo, E. B. G. Jones \& } \\
\text { K. L. Pang }\end{array}$ & & & & + & & & \\
\hline Sporormiella megalospora (Auersw.) S. I. Ahmed \& Cain & - & + & - & - & - & - & - \\
\hline$\approx$ Stachybotrys chartarum (Ehrenb.) S. Hughes & + & + & - & + & + & + & + \\
\hline Stemphylium beticola Woudenb. \& Hanse & - & + & + & + & - & - & - \\
\hline Stemphylium sp. & - & - & - & + & + & + & - \\
\hline Toriella tubulifera (Kohlm.) Sakay., K. L. Pang \& E. B. G. Jones & - & - & - & + & - & - & - \\
\hline$\approx$ Torpedospora radiata Meyers & - & - & - & + & - & - & - \\
\hline$\approx$ Trichoderma viride Pers. & + & + & + & - & - & + & - \\
\hline Verruculina enalia (Kohlm.) Kohlm. \& Volkm.-Kohlm. & & + & - & & & & \\
\hline Zalerion maritimum (Linder) Anastasiou & - & + & - & + & + & - & + \\
\hline \multicolumn{8}{|c|}{ Basidiomycota } \\
\hline$\approx$ Digitatispora marina Doguet & - & - & - & + & - & - & - \\
\hline Nia globospora Barata \& Basilio & - & - & - & + & - & - & - \\
\hline$\approx N$. vibrissa $\mathrm{R}$. T. Moore \& Meyers & - & - & - & + & - & - & - \\
\hline \multicolumn{8}{|c|}{ Mucoromycota } \\
\hline Cunninghamella elegans Lendn., Bull. Herb. Boissier & - & + & + & - & - & - & - \\
\hline Mortierella sp. & - & + & + & - & - & - & - \\
\hline Mucor ramosissimus Samouts. & - & + & + & - & - & + & - \\
\hline Mucor sp. & - & + & - & - & - & - & - \\
\hline $\begin{array}{l}\text { Rhizopus arrhizus A. Fisch., in Winter, Rabenh. } \\
\text { Krypt.-Fl. }\end{array}$ & - & + & + & - & - & - & - \\
\hline R. stolonifer (Ehrenb.) Vuill. & - & + & + & - & - & - & - \\
\hline \multicolumn{8}{|c|}{ Chromista-Oomycota } \\
\hline Ostracoblabe implexa Bornet \& Flahault & - & - & + & - & - & - & - \\
\hline
\end{tabular}

Note: "-" - species of fungus was not found on this type of substrate; " + " - species occurred in 1-25\% on this type of substrate; " ++ " - fungus species occurred in $26-50 \%$ on this type of substrate; " $+1+$ " - species occurred in $51-100 \%$ on this type of substrate; $\approx-$ species of fungus has a confirmed ability to function in marine environment (according to Jones et al., 2015, 2019); $\mathrm{p}$ - fungus species is pathogenic to human (BSL-2) (De Hoog et al., 2000).

Bray-Curtis coefficient revealed minimum similarity between the species compositions of the communities of driftwood and concrete - 21.1 (10 shared species), maximal - on shells of M. galloprovincialis (3 and $7 \mathrm{~m}$ ) and C. gigas $-72.7 \%$ (45 shared species). On the surfaces with similar chemical content, for example, concrete and stones (69.1\%), driftwood and attached wood (47.8\%), the greatest similarities of the compositions of species were determined. However, community of fungi on shells of $M$. galloprovincialis at the depth of $0.3 \mathrm{~m}$ was less similar to the communities on the shells of $M$. galloprovincialis at the depths of 3 and $6 \mathrm{~m}-$ 58.8 (31 shared species) and the shells of $C$. gigas $-39.0 \%$ (15 shared species) (Fig. 2a, 2b).
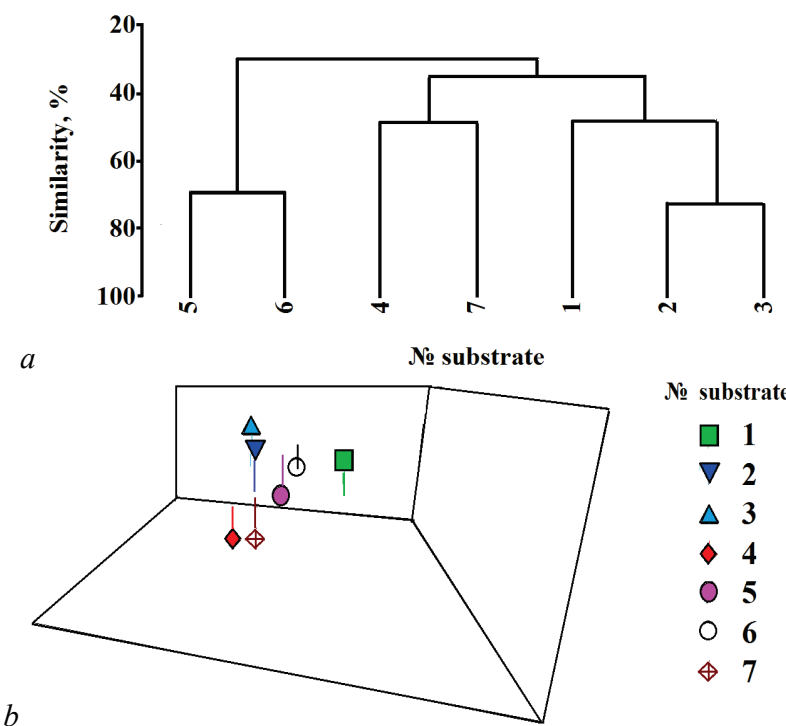

Fig. 2. Cluster ( $a$ ) analysis and MDS (3D) (b) ordination of similarity of species composition of fungi on various substrates in the Black Sea: communities of fungi on substrates: 1 - shells of Mytilus galloprovincialis, $0.3 \mathrm{~m}$ depth; 2 - shells of $M$. galloprovincialis, 3 and $7 \mathrm{~m}$ depth; 3 - shells of Crassostrea gigas; 4 -drigtwood; 5-stones; 6 -hydrotechnical constructions (concrete); 7 -wood between between concrete blocks of hydrotechnic constructions
Species similarity indices reflect only the number of species the communities' share, while providing no data on complexity of taxonomic structures of communities at the levels higher than species. To make a comparative assessment of deviations from the systemic structure of mycological communities, we developed graphs of taxonomic indices: $\operatorname{AvTD}\left(\Delta^{+}\right)$and its variation $\operatorname{VarTD}\left(\Lambda^{+}\right)$for studied substrates (Fig. 3a, $3 \mathrm{~b}$ ). Symbols of values of index $\Delta+$ (Fig. 3a) for mycological communities on the shells of M. galloprovincialis at the depths of 3 and $7 \mathrm{~m}(2)$ and C. gigas (3) are located on the line of the average expected value, indicating the relative evenness of the structure of these communities according to higher taxonomic ranks. In those mycological communities, the species of fungi were represented in 7-8 classes (out of 10), 2-3 divisions, on the shells of $M$. galloprovincialis from 1 kingdom, on the shells of $C$. gigas 2 kingdoms. Symbols of values of index which correspond to the remaining substrates are under the lower threshold of the graph of trust-funnel, because the species of fungi that they contain belong to 4-6 classes of 12 divisions, 1 kingdoms. Minimal value of the index was calculated for the community of stones: 29 species were found belong to 4 classes, 1 division. In the mycological community of driftwood (4), 67 species belong to 6 classes of 2 divisions of Fungi kingdom. Long influence of natural unfavourable factors is believed to have led to simplification of the structure of the community due to death of some individuals, populations and even species, while the number of taxa of higher rank decreased. In this case, index $\Delta+$ has minimum value (Clarke \& Warwick, 1998). In our case, the lowest values of the indices were observed for communities of fungi which developed on periodically drying substrates, and therefore are in extreme conditions.

In the graph of values of $\Lambda+$ index (Fig. 3b), symbols of 5 mycological communities are within the graph of trust-funnel. These communities of fungi comprise 4-9 classes, 2 divisions of the Fungi kingdom. Symbols of mycological communities of concrete (6) and C. gigas (3) are under the upper threshold of trust-funnel, which means high disproportion in the distribution of number of species in high horizontal levels. In mycological communities of concrete, 26 species of fungi were found belonging to 4 classes, 2 divisions, 1 kingdom. Disproportionate pattern in taxonomic structure of mycological community manifests in presence of 25 species of fungi of the Ascomycota division (96.1\%), and one species $(0.9 \%)$ of the Mucoromycota division. In the mycological community of shells of C. gigas, there were found 47 species of 7 classes, 3 divisions, 2 king- 
doms. Kingdom Fungi: division Ascomycota - 41 species (87.3\%), division Mucoromycota -5 species (10.6\%). Kingdom Chromista -1 species (2.1\%). The higher the level of taxonomic rank, represented by minimal number of species in the community, the higher the value of index $\Lambda^{+}$ (Clarke \& Warwick, 2001; Clarke et al., 2014).

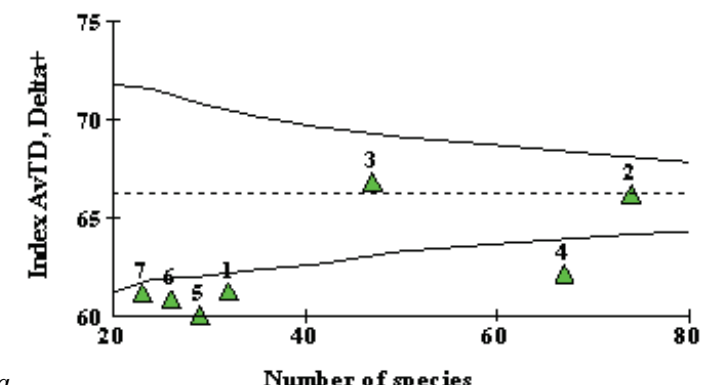

$a$

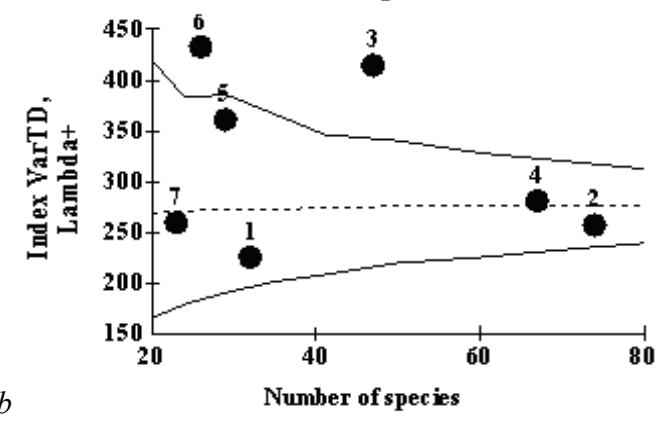

Fig. 3. Values of indices of taxonomic distinctiveness AvTD, Delta+ (a) and its variation VarTD, Lambda $+(b)$ of fungi communities on various substrates based on the whole list of species on various substrates: communities of fungi on substrates: 1 - shells of Mytilus galloprovincialis, $0.3 \mathrm{~m}$ depth; 2 - shells of $M$. galloprovincialis, 3 and $7 \mathrm{~m}$ depth; 3 - shells

of Crassostrea gigas; 4 -driftwood; 5 -stones; 6 -concrete

(hydrotechnical constructions); 7-wood between the concrete blocks of hydrotechnical constructions

Using graph of index $\Delta+$ demonstrates specifics in the systematic structure of mycological communities of various substrates. Using index $\Lambda+$ helped us to determine the most complex taxonomic structure of communities of fungi which developed on concrete and shells of $C$. gigas.

\section{Discussion}

Many species of fungi occur in marine and terrestrial biotopes, and therefore we compiled the list of species of fungi on similar or chemically close substrates from various regions of the world using the literature data. We used * sign to indicate substrates on which the included fungi grew using the literature data, the authors of the studies are written in the note to Table 2. Limestone and marble are sedimentary rocks, of mostly biogenic origins, composed of shells and skeletons of marine animals, chemical base - calcium carbonate $\left(\mathrm{CaCO}_{3}\right)$. Taking into account our data, the list of fungi comprises 445 species of 240 genera, 103 families, 51 orders, 15 classes, 5 divisions, 2 kingdoms. The number of fungi taxa on the substrates up to the level of class is demonstrated in Table 2. The number of higher taxonomic ranks changed in the following way: classes - from 4 (stones, concrete, wood between concrete blocks) to 11 (shells of Bivalvia*); divisions - from 1 (M. galloprovincialis, 0.3 depth, stones, wood between concrete blocks) to 5 (limestone*); kingdoms - from 1 (M. galloprovincialis on different depths, stones, concrete, concrete*, on all cellulose-containing substrates) to 2 (C. gigas, limestone*, marble*, shells of Bivalvia mollusks*). In the list, no species, genera and families of fungi which were shared by all the substrates were found. Representatives of orders Hypocreales (Sordariomycetes class) and Pleosporales (Dothideomycetes class) order Ascomycota, Fungi kingdom were present on all the types of substrates, the greatest number of species was found for four divisions (Table 2).

The list of authors whose works were used to compile the list of species is as follows: shells of Bivalvia* (Zvereva \& Vysotskaya, 2005; Pirkova \& Demenko, 2008; Borzykh, \& Zvereva, 2012a, 2014; Doroshenko, 2013; Kopytina \& Lebedovskaya, 2014; Nambiar \& Raveendran, 2015; Jones et al., 2019); driftwood* (Nambiar \& Raveendran, 2008; Nambiar et al., 2008; Immaculatejeyasanta et al., 2012; Gonçalves et al., 2019; Tibell et al., 2020); tidal wood (mangrove trees)* (Nambiar \& Raveendran, 2008; Awaluddin et al., 2015; Abdel-Wahab et al., 2018; Jones et al., 2019; Tamayo-Cevallos, 2020); concrete* (Cwalina, 2008; Vlasov, 2011; Karamova et al., 2014; Yakovleva et al., 2018; Mantilla et al., 2019; Svetlov \& Kachalov, 2019; Elkhateeb et al., 2021); limestone (Zelenskaya \& Vlasov, 2006; Cwalina, 2008; Lian et al., 2008); marble* (Zelenskaya \& Vlasov, 2006; Cwalina, 2008; Lian et al., 2008); natural stones* (Zelenskaya \& Vlasov, 2001, 2006; Mosyagin et al., 2009; Vlasov, 2011; Popova et al., 2014); wood in structures (Serova \& Titova, 2014; Ion et al., 2018)

Table 2

Number of species/families of fungi and the share (\%) of dominating orders within the communities on various substrates and in various biotopes

\begin{tabular}{|c|c|c|c|c|c|c|c|}
\hline Biotope & Substrate & $\begin{array}{c}\text { Number } \\
\text { of species / families }\end{array}$ & $\begin{array}{l}\text { Number } \\
\text { of orders }\end{array}$ & Hypocreales & Pleosporales & Eurotiales & Microascales \\
\hline \multicolumn{8}{|c|}{ Our data } \\
\hline Sea-land-air & Mytilus galloprovincialis, $0.3 \mathrm{~m}$ depth & $31 / 10$ & 10 & 6.5 & 12.9 & 16.1 & 32.3 \\
\hline Sea & Mytilus galloprovincialis, 3 and $7 \mathrm{~m}$ depth & $76 / 23$ & 15 & 6.7 & 30.7 & 13.3 & 14.7 \\
\hline Sea & Crassostrea gigas, $4-12 \mathrm{~m}$ depth & $46 / 14$ & 10 & 6.7 & 33.3 & 17.8 & 11.1 \\
\hline Sea-land-air & Driftwood & $67 / 20$ & 14 & 3.2 & 30.2 & 1.6 & 33.3 \\
\hline Sea-land-air & Stones, 0 to $0.3 \mathrm{~m}$ above sea level & $27 / 10$ & 10 & 3.7 & 29.6 & 29.6 & 3.7 \\
\hline Sea-land-air & Concrete, 0 to $0.3 \mathrm{~m}$ above sea level & $25 / 9$ & 7 & 12.0 & 28.0 & 40.0 & 0.0 \\
\hline Sea-land-air & Wood between concrete blocks, 0 to $0.3 \mathrm{~m}$ above sea level & $20 / 10$ & 8 & 5.0 & 30.0 & 5.0 & 30.0 \\
\hline \multicolumn{8}{|c|}{ Literature data } \\
\hline Sea & Bivalvia shells* & $59 / 22$ & 16 & 14.3 & 7.1 & 28.6 & 17.9 \\
\hline Sea-land-air & Driftwood* & $125 / 31$ & 16 & 4.6 & 25.7 & 13.8 & 39.4 \\
\hline Sea-land-air & Tidal wood* (mangrove trees) & $99 / 36$ & 16 & 7.1 & 60.7 & 0.0 & 42.9 \\
\hline Land-air & Limestone* & $63 / 24$ & 16 & 22.2 & 17.5 & 15.9 & 0.0 \\
\hline Land-air & Marble* & $93 / 33$ & 24 & 15.1 & 18.3 & 16.1 & 1.1 \\
\hline Land-air & Stones* & $90 / 33$ & 22 & 24.6 & 14.8 & 26.2 & 3.3 \\
\hline Land-air & Concrete* & $27 / 16$ & 14 & 15.0 & 5.0 & 50.0 & 5.0 \\
\hline Land-air & Wood in constructions* & $77 / 20$ & 16 & 10.5 & 13.2 & 43.4 & 2.6 \\
\hline
\end{tabular}

Note: sea-constantly submerged substrates; sea-land-air-periodically flooded substrates; ${ }^{*}$ - list of species of fungi is composed using the literature data.

Most analyzed mycological communities were located on the borders of the 1st and 3rd media, and therefore the structures of communities of fungi were analyzed according to living locations. The following types were distinguished - marine: shells of $M$ galloprovincialis ( 3 and $7 \mathrm{~m}$ depths), C. gigas (4-12 m depth) and shells of Bivalvia*; land-air: concrete*, stones*, marble*, limestone*, wood in structures*; sea-land-air: shells of M. galloprovincialis (0.3 m depth), driftwood, stones (height from 0 to $0.3 \mathrm{~m}$ above sea level), concrete (height from 0 to $0.3 \mathrm{~m}$ above sea level), wood between concrete blocks (height from 0 to $0.3 \mathrm{~m}$ above sea level), driftwood*, tidal wood*(mangrove trees). The number of species also varied in biotopes, 117 in sea to 244 in biotope sea-land-air. According to dominating orders, the number of species (share \%) in bio- 
topes was distributed as follows. Species of Hypocreales order (38 species, 15 genera, 6 families) dominated in the land-air biotope - 30 species $(14.5 \%)$, in sea -10 species $(8.5 \%)$, in the biotope sea-land-air - 11 (9.4\%). Shared species were Acremoniun sp. (incertae sedis), F. oxysporum (Nectriaceae), S. chartarum (Stachybotryaceae), T. viride (Hypocreaceae). Species of Pleosporales order (94 species, 54 genera, 27 families) dominated in the biotope sea-land-air - 64 species $(26.2 \%)$, in land 30 species $(14.5 \%)$, in sea $-25(21.4 \%)$. Species of fungi with shared biotopes were $A$. alternata, A. cichorii, A. tenuissima (Pleosporaceae), Epicoccum sp., Phoma sp. (Didymellaceae). For the order Eurotiales (61 species, 4 genera, 1 families), maximal number of species was seen in the biotope land-air 46 (22.2\%), in sea - 21 (10.1\%), in the biotope sealand-air-24 (9.8\%). Shared species were A. fumigatus, A. flavus, A. nidulans, A. niger, A. sydowii, Aspergillus sp., P. aurantiogriseum, Penicillium exspansum, Penicillium sp. (Aspergillaceae). Almost all species of this order are pathogens of opportunistic diseases.

Saprotrophs, representatives of Microascales order (69 species, 36 genera, 4 families) dominated in biotope sea-land-air - 63 species (25.8\%), in sea -19 species (7.8\%), in biotope land-air -5 species $(2.0 \%)$. By the number of species, family Halosphaeriaceae dominated $(24.6 \%$, 30 genera), in the sea $(13.7 \%, 8$ genera), though no representatives of the family were found on land. The most numerous genus was Corollospora (12 species); on cellulose-containing substrates and shells of mollusks, the shared species were $C$. angusta, $C$. intermedia, $C$. trifurcata. On land, there occurred Ceratocystis paradoxa (Dade) C. Moreau (Ceratocystidaceae) (marble*), Ceratocystys sp. (Ceratocystidaceae) (wood in constructions*), Microascus brevicaulis S. P. Abbott (Microascaceae) (wood in constructions*, stones*), Acaulium acremonium (Delacr.) Sand.-Den., Guarro \& Gené (Microascaceae) (stones*).

Similarity of species composition in biotopes varied $16.0 \%$ (biotopes land-air and sea-land-air, 32 shared species) to $36.6 \%$ (biotopes sea and sea-land-air, 57 shared species). In the marine environment, a minimal number of taxa was found- 117 species, 64 genera, 31 families, 18 orders, 11 classes, 4 divisions, 2 kingdoms. In the biotope land-air, at all the levels, a number of taxa was seen -207 species, 100 genera, 56 families, 35 orders, 13 classes, 5 divisions, 2 kingdoms. In the biotope sea-land-air, we recorded maximal number of taxa up to the level of family -244 species, 144 genera, 57 families, but at higher levels, the diversity decreased 27 orders, 10 classes, 3 divisions of the Fungi kingdom. The disproportionate structure of the sea-land-air biotope manifests in the concentration of species composition in the divisions Pleosporales, Microascales $-52.0 \%$. Accordingly, in extreme conditions of sea-land-air, the taxonomic structure of mycological communities becomes less complex, for the number of higher ranks decreases. Specifics in the structure of biotopes are reflected in graphs of indices $\Delta+$ and $\Lambda+$ (Fig. 4).

The research revealed that in mycological communities on substrates that were closely related by chemical composition, species of the same divisions (genus and families may vary) dominated in all biotopes: orders Hypocreales, Pleosporales, Eurotiales (genera Acremonium, Fusarium, Alternaria, Aspergillus, Penicillium) in biotope land-air; Pleosporales, Eurotiales, Microascales (Alternaria, Aspergillus, Penicillium, Corollospora) in the sea; Pleosporales, Microascales (Alternaria, Leptosphaeria, Aspergillus, Penicillium, Corollospora, Halosarpheia) in sea-land-air.

Recognized indicators of technogenic pressure on the environment are dominance of fungi that contain melanin (for example, species of fungi which belong to division Pleosporales, and also genera Cirrenalia, Cumulospora, Humicola and some other) and micromycetes that produce toxins (division Eurotiales, and also genera Alternaria, Cladosporium, Stachybotrys). Melanin pigments and toxins increase the ability of fungi to survive in unfavourable conditions (Marfenina, 2005). In fouling mycological communities of the Black Sea, the share of melanin-containing fungi was high on all the substrates - from 52.0 (concrete) to $-66.7 \%$ (stones), the share of toxin-containing fungi-from 19.4 (shells of M. galloprovincialis, 0.3 depth) to $60 \%$ (concrete). This is likely the manifestation of the impact of heightened anthropogenic pressure on the ecosystems - ports (Odesa, Sevastopol) and terrigenous runoff of various origins. In mycological communities composed according to the literature data, the minimal share of melanin-containing fungi was on concrete surfaces, equaling $18.5 \%$, and maximal (41.4\%) was on tidal wood. Toxin-producing fungi in my- cological communities of mangrove thickets accounted for $2.0 \%$, while highest number of species was on wood of structures (43.4\%). The share of melanin-containing fungi was high in the communities of all the biotopes, varying 30.9 (land-air) to $42.2 \%$ (sea-land-air). In the sea biotope, there was seen the highest share of fungi that generate toxins $(30.8 \%)$, many of them had terrestrial origin.
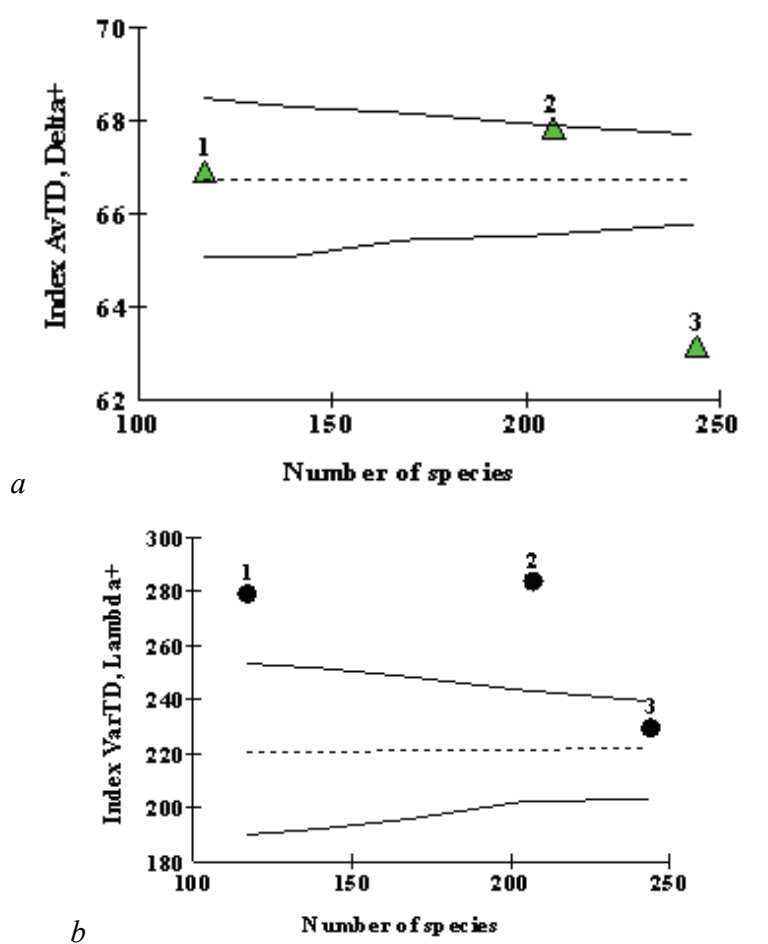

Fig. 4. Values of indices of taxonomic distinctness of AvTD, Delta+ $(a)$ and its variability VarTD, Lambda+ $(b)$ of fungi communities on various

substrates based on the whole list of species in different biotopes: communities of fungi on biotopes: 1 - sea; 2 -sea-air; 3 - sea-land-air

In mycological communities of mollusks, stones and concrete, $A$. fumigatus (Zelenskaya \& Vlasov, 2006; Borzykh \& Zvereva, 2014) often occurs. While being cultivated on media with marine water, this fungus produced cytotoxic and immune depressing toxin, gliotoxin. Six days following the contamination, the toxin accumulated on the meat of mussels at the level up to $2.9 \mu \mathrm{m} / \mathrm{mg}$ of the extract (Grovel et al., 2003). Fungi species Aspergillus, Penicillium, Cladosporium and Chaetomium produce mycotoxins and dominate by species composition in mycobiota of shells and internal organs of mollusks, and therefore consuming them can cause intoxication in people (Sallenave-Namont et al., 2000; Zvereva \& Vysockaya, 2005).

In mycological communities of mollusks, there were found soil ascomycete Pseudallescheria boydii (=Monosporium apiospermum Sacc. $=$ Allescheria boydii Shear) and its anamorphic stage Scedosporium apiospermum Sacc. ex Castell. \& Chalm. - causative agents of monosporiosis or allescheriosis. The infection caused by Scedosporium is potentially dangerous to humans, being able to lead to lethal outcome, and is hard to diagnose and treat. Humans often catch this disease after water has entered their lungs, the infection frequency increases as a result of environmental contamination (Guarro et al., 2006).

The fungi-like organism $O$. implexa, present in the mycological community of oysters, is responsible for shell disease. As a result of epizooty of Black Sea mollusks Ostrea edulis and O. lamellosa, caused by this organism, they have become a threatened species in the northwest part of the Black Sea and the Crimean coast. Since 2000s, this parasite has also occurred on shells of $C$. gigas cultivated in the Crimea (Pirkova, 2002; Pirkova \& Demenko, 2008).

Secondary metabolites of marine fungi, many substances isolated from fungi which have anti-tumour and antibacterial activities are increasingly becoming the focus of scientific articles (Orlova et al., 2017; Afiyatullov \& Zhuravleva, 2019; Bocharova et al., 2021). 


\section{Conclusions}

The role of fungi is significant in the functioning of any ecosystem they consume and mineralize organic and inorganic substances, and therefore promote purification of the environment and create conditions for development of other organisms. Currently, there are no effective means for protecting natural and anthropogenic materials from deterioration caused by fungi. High resistance of fungi to many contaminating agents, numerous ways of reproduction, and their ability to produce toxins and melanin ensure their survivability. Technogenic pressure on ecosystems leads to natural selection of fungi that generate toxins and melanin (Marfenina, 2005). In our research, this pattern manifested especially distinctly the share of melanin-containing fungi was very high on all the substrates from $52.0 \%$ (concrete) to $-66.7 \%$ (stones), the share of toxin-producing fungi - from $19.4 \%$ (shells of $M$. galloprovincialis, 0.3 depth) to $60.0 \%$ (concrete). Fungi are also a food component for many invertebrates and fish, and therefore toxins may accumulate in the organism of animals and lead to food intoxications of people. Secondary metabolites of fungi are used in the food industry, and also are promising objects for search of new active substances for production of medicinal preparations. Thus, the main problem is identification of pathogenic species of fungi in mycological communities at recreation sites, marine economic sectors, objects of the food industry, construction materials, museums, warehouses, apartments, healthcare facilities, swimming pools etc., to prevent infestation with mycological infections and intoxication with toxins that fungi produce.

This work was carried out within the frameworks of government research assignment of IBSS RAS "Investigation of the mechanisms of controlling production processes in biotechnological complexes with the aim of developing the scientific foundations for the production of biologically active substances and technical products of marine genesis" No. 121030300149-0.

The authors claim no conflict of interests.

\section{References}

Abdel-Wahab, M., Jones, E. B. G., Bahkali, A. H. A., \& El-Gorban, A. M. (2019). Marine fungi from Red Sea mangroves in Saudi Arabia with Fulvocentrum rubrum sp. nov. (Torpedosporales, Ascomycota). Nova Hedwigia, 108(3), 1-13.

Afiyatullov, S. S., \& Zhuravleva, O. I. (2019). Sovmestnoe kul'tivirovanie morkkih gribov-mikromicetov - perspektivnyj sposob polucheniya novyh bioaktivnyh vtorichnyh metabolitov [Co-cultivation of marine micromycetes fungi is a promising way of obtaining new bioactive secondary metabolites]. Vestnik DVO RAN, 5, 57-65 (in Russian).

Alker, A. P., Smith, G. W., \& Kim, K. (2001). Characterization of Aspergillus sydowii (Thom et Church), a fungal pathogen of Caribbean Sea fan corals. Hydrobiologia, 460, 105-111.

Amend, A., Burgaud, G., Cunliffe, M., Edgcomb, V. P., Ettinger, C. L., Gutiérrez, M. H., Heitman, J., Hom, E. F. Y., Ianiri, G., Jones, A. C., Kagami, M., Picard, K. T., Quandt, C. A., Raghukumar, S., Riquelme, M., Stajich, J., Vargas-Muñiz, J., Walker, A. K., Yarden, O., \& Gladfelter, A. S. (2019). Fungi in the marine environment: Open questions and unsolved problems. mBio, 10(2), e01189-18.

Ananda, K., Prasannarai, K., \& Sridhar, K. R. (1998). Occurrence of higher marine fungi on marine animal substrates of some beaches along the west coast of India. Indian Journal of Geo-Marine Sciences, 27(2), 233-236.

Awaluddin, H. H., Nor, N. A. M., Nor, H. M., Sharuddin, S. S., Pang, K.-L., Mohamad-Fauzi, N., Rizman-Idid, M., \& Alias, S. A. (2015). Biodiversity of marine lignicolous fungi from mangroves of Sulu Sea. Malaysian Journal of Science 34(1), 43-57.

Barinova, K. V., Vlasov, D. Y., Shchiparev, S. M., Zelenskaya, M. S., Rusakov, A. V., \& Frank-Kameneckaya, O. V. (2010). Organicheskie kisloty mikromicetov, izolirovannyh s kamenistyh substratov [Organic acids of microfungi isolated from the rock substances]. Mikologiya i Fitopatologiya, 44(2), 137-142. (in Russian).

Bilaj, V. I., \& Koval', E. Z. (1988). Aspergilly [Aspergillus]. Naukova Dumka, Kiev. (in Russian).

Bindschedler, S., Cailleau, G., \& Verrecchia, E. (2016). Role of fungi in the biomineralization of calcite. Minerals, 6,41 .

Bocharova, E. A., Kopytina, N. I., \& Slynko, E. E. (2021). Anti-tumour drugs of marine origin currently at various stages of clinical trials (Review). Regulatory Mechanisms in Biosystems, 12(2), 265-280.

Borzyh, O. G., \& Zvereva, L. V. (2012). Micelial'nye griby v epibioze primorskogo grebeshka Mizuhopecten yessoensis (Bivalvia) v zalive Petra Velikogo Yapon- skogo morya [Mycelial fungi in the epibiosis of the seaside scallop Mizuhopecten yessoensis (Bivalvia) in the Peter the Great Bay of the Sea of Japan]. Biologiya Morya, 38(6), 483-484 (in Russian).

Borzyh, O. G., \& Zvereva, L. V. (2012a). Mikobiota gigantskoj ustricy Crassostrea gigas (Thunberg, 1787) (Bivalvia) iz zaliva Petra Velikogo Yaponskogo moray [Mycobiota of the giant oyster Crassostrea gigas (Thunberg, 1787) (Bivalvia) from Great Peter Bay of the Sea of Japan]. Mikrobiologiya, 81(1), 117-119 (in Russian).

Borzyh, O. G., \& Zvereva, L. V. (2014). Sravnenie gribnyh kompleksov primorskogo grebeshka Mizuhopecten yessoensis (Jay, 1856) iz razlichnyh rajonov zaliva Petra Velikogo Yaponskogo moray [Comparison of mushroom complexes of the seaside scallop Mizuhopecten yessoensis (Jay, 1856) from various areas of Peter the Great Bay of the Sea of Japan]. Mikrobiologiya, 83(5), 599-604 (in Russian).

Borzyh, O. G., \& Zvereva, L. V. (2015). Mikobiota dvustvorchatogo mollyuska Anadara broughtoni (Schrenck, 1867) (Bivalvia: Arcideae) iz zaliva Petra Velikogo Yaponskogo moray [Mycobiota of the bivalve mollusk Anadara broughtoni (Schrenck, 1867) (Bivalvia: Arcidae) from Great Peter Bay of the Sea of Japan]. Biologiya Morya, 41(4), 290-291 (in Russian).

Bubnova, E. N., Grum-Grzhimailoa, O. A., \& Kozlovsky, V. V. (2020). Composition and structure of the community of mycelial fungi in the Bottom Sediments of the White Sea. Moscow University Biological Sciences Bulletin, 75(3), 153-158.

Clarke, K. R., \& Warwick, R. M. (1998). A taxonomic distinctness index and its statistical properties. Journal of Applied Ecology, 35, 523-531.

Clarke, K. R., \& Warwick, R. M. (2001). A further biodiversity index applicable to species lists: Variation in taxonomic distinctness. Marine Ecology Progress Series, 216, 265-278.

Clarke, K. R., Gorley, R. N., Somerfield, P. J., \& Warwick, R. M. (2014). Change in marine communities: An approach to statistical analysis and interpretation. 3rd edition. Primer-E, Plymouth.

Cwalina, B. (2008). Biodeterioration of concrete. Architecture Civil Engineering Environment, 1(4), 133-140.

De Hoog, G. S., Guarro, J., Gene, J., \& Figueras, M. J. (2000). Atlas of clinical fungi. CBS, Utrecht, Reus.

Doroshenko, Y. V. (2013). Harakteristika rosta massovyh vidov drozhzhej perifitona sistem gidrobiologicheskoj ochistki morskih vod [Characteristics of the growth of mass yeast species of periphyton systems of hydrobiological purification of marine waters]. Byuleten' DNBS, 109, 13-17 (in Russian).

Elkhateed, W. A., Elnahas, M. O., \& Daba, G. M. (2021). Review: Microbial induced mineralization of calcium carbonate for self-healing concrete. Asian Journal of Natural Product Biochemistry, 19(1), 1-9.

Gebruk, A. A., Borisova, P. B., Glebova, M. A., Basin, A. B., Simakov, M. I., Shabalin, N. V., \& Mokievsky, V. O. (2019). Macrozoobenthos of the shallow waters of Pechora Bay (SE Barents Sea). Nature Conservation Research, 4(4), 1-11.

Gleason, F. H., Gadd, G. M., Pitt, J. I., \& Larkum, A. W. D. (2017). The roles of endolithic fungi in bioerosion and disease in marine ecosystems. I. General concepts. Mycology, 8(3), 205-215.

Gleason, F. H., Gadd, G. M., Pitt, J. I., \& Larkum, A. W. D. (2017). The roles of endolithic fungi in bioerosion and disease in marine ecosystems. II. Potential facultatively parasitic anamorphic ascomycetes can cause disease in corals and molluscs. Mycology, 8(3), 216-227.

Gnavi, G., Garzoli, L., Poli, A., Prigione, V., Burgaud, G., Giovanna, \& Varese, G. C. (2017). The culturable mycobiota of Flabellia petiolata: First survey of marine fungi associated to a Mediterranean green alga. PLoS One, 12(4), e0175941.

Gonçalves, M. F. M., Santos, L., Silva, B. M. V., Abreu, A. C., Vicente, T. F. L., Esteves, A. C., \& Alves, A. (2019). Biodiversity of Penicillium species from marine environments in Portugal and description of Penicillium lusitanum sp. nov., a novel species isolated from sea water. International Journal of Systematic and Evolutionary Microbiology, 69, 3014-3021.

Greco, G., Capello, M., Cecchi, G., Cutroneo, L., Di Piazza, S., \& Zotti, M. (2017). Another possible risk for the Mediterranean Sea? Aspergillus sydowii discovered in the Port of Genoa (Ligurian Sea, Italy). Marine Pollution Bulletin, 122, $470-474$.

Grovel, O., Pouchus, Y., \& Verbist, J. (2003). Accumulation of gliotoxin, a cytotoxic mycotoxin from Aspergillus fumigatus, in blue mussel (Mytilus edulis). Toxicon, 42(3), 297-300.

Guarro, J., Kantarcioglu, A. S., Horré, R., Rodriguez-Tudela, J. L., Estrella, M. C., Berenguer, J., \& De Hoog, G. S. (2006). Scedosporium apiospermum: changing clinical spectrum of a therapy-refractory opportunist. Medical Mycology, 44, 295-327.

Hudyakova, Y. V., Kirichuk, N. N., Pivkin, M. V., \& Butorina, T. E. (2017). Gribyassocianty primorskogo grebeshka Mizuhopecten yessoensis Jay, $1875 \mathrm{v}$ usloviyah marikul'tury (buhta Severnaya, zaliv Slavyanskij, Yaponskoe more) [Associated fungi of the Yesso scallop Mizuhopecten yessoensis Jay, 1875 under mariculture conditions (Severnaya Bay, Slavyansky Bay, Sea of Japan)]. Uspekhi Sovremennoj Nauki, 2(5), 218-222 (in Russian). 
Immaculatejeyasanta, K., Madhanraj, P., Patterson, J., \& Panneerselvam, A. (2012). Diversity of driftwood associated marine fungi of the Muthupet mangrove of Tamilnadu, India. Elixir Bio Diversity, 42A, 6544-6548.

Ion, R.-M., Grigorescu, R.-M., Iancu, L., Ghioca, P., \& Radu, N. (2018). Polymeric micro- and nanosystems for wood artifacts preservation. In: Pagnola, M. R., Vivero, J. U., \& Marrugo, A. G. (Eds.). New uses of micro and nanomaterials. IntechOpen, London. Pp. 74-93.

Jin, C., Yu, R., \& Shui, Z. (2018). Fungi: A neglected candidate for the application of self-healing concrete. Frontiers in Built Environment, 4, 62.

Jones, E. B. G., Pang, K.-L., Abdel-Wahab, M. A., Scholz, B., Hyde, K. D., Boekhout, T., Ebe, R., Rateb, M. E., Henderson, L., Sakayaroj, J., Suetrong, S., Dayarathne, M. C., Kumar, V., Raghukumar, S., Sridhar, K. R., Bahkali, A. H. A., Gleason, F. H., \& Norphanphoun, C. (2019). An online resource for marine fungi. Fungal Diversity, 96, 347-433.

Jones, E. B. G., Sakayaroj, J., Suetrong, S., Somrithipol, S., \& Pang, K. L. (2009). Classification of marine Ascomycota, anamorphic taxa and Basidiomycota. Fungal Diversity, 35, 1-187.

Jones, E. B. G., Suetrong, S., Sakayaroj, J., Bahkali, A. H., Abdel-Wahab, M. A. Boekhout, T., \& Pang, K.-L. (2015). Classification of marine Ascomycota, Basidiomycota, Blastocladiomycota and Chytridiomycota. Fungal Diversity, 73 , $1-72$.

Karamova, N. S., Nadeeva, G. V., \& Bagaeva, T. V. (2014). Metody issledovaniya ocenki biopovrezhdenij, vyzyvaemyh mikroorganizmami (uchebno-metodicheskoe posobie) [Methods of research and evaluation of biological damage caused by microorganisms (educational and methodological manual)]. Kazanskij Universitet, Kazan' (in Russian).

Kohlmeyer, J. (1969). The role of marine fungi in the penetration of calcareous substances. American Zoologist, 9, 741-746.

Kohlmeyer, J., \& Kohlmeyer, E. (1979). Marine mycology. The higher fungi. Academic Press, New York.

Kopytina, N. I. (2020). Mikobiota pelagiali Odesskogo regiona severo-zapadnoj chasti Chyomogo moria [Microbiota of the pelagial of the Odessa region of the north-western part of the Black Sea]. Vestnik Tomskogo Gosudarstvennogo Universiteta, Biologiya, 52, 140-163 (in Russian).

Kopytina, N. I., \& Lebedovskaya, M. V. (2014). Mikromicety - epibionty gigantskoj ustricy Crassostrea gigas, kul'tiviruemoj v Chernom more [Micromycetes-epibionts of the Pacific giant oyster Crassostrea gigas, cultivated in the Black Sea]. Morskoj Ekologicheskij Zhurnal, 12(13), 41-44 (in Russian).

Li, Q., Csetenyi, L., \& Gadd, G. M. (2014). Biomineralization of metal carbonates by Neurospora crassa. Environmental Science and Technology, 48(24), 14409 14416.

Li, Q., Csetenyi, L., Paton, G. I., \& Gadd, G. M. (2015). $\mathrm{CaCO}_{3}$ and $\mathrm{SrCO}_{3}$ bioprecipitation by fungi isolated from calcareous soil. Environmental Microbiology, 17(8), 3082-3097.

Lian, B., Chen, Y., Zhu, L., \& Yang, R. (2008). Effect of microbial weathering on carbonate rocks. Earth Science Frontiers, 15(6), 90-99.

Luo, J., Chen, X., Crump, J., Zhou, H., Davie, D., Zhou, G., \& Jin, C. (2018). Interactions of fungi with concrete: Significant importance for bio-based self-healing concrete. Construction Building Materials, 164, 275-285.

Magan, N. (2007). Fungi in extreme environment. In: Kubicek, C. P., \& Druzhinina, I. S. (Eds.). Environmental and microbial relationships. The mycota IV. Springer-Verlag, Berlin.

Mantilla, K., Suárez-Barrera, M., Rueda-Forero, N. J., Guarín, O. D., Gómez, F. R. Durán, S. M., \& Tiria, L. C. (2019). Characterization of biodeteriorating microorganisms in buildings in Bucaramanga, Colombia. Journal of Physics: Conference Series, 1386, 012104.

Marfenina, O. E. (2005). Antropogennaya ekologiya pochvennyh gribov [The anthropogenic ecology of soil fungi]. "Meditsina Dlya Vsekh" Natsional'naya Akademiya Mikologii, Moscow (in Russian).

Martuscelli, C., Soares, C., Camões, A., \& Lima, N. (2020). Potential of fungi for concrete repair. Procedia Manufacturing, 46, 180-185.

Menon, R. R., Luo, J., Chen, X., Zhou, H., Liu, Z., Zhou, G., Zhang, N., \& Jin, C. (2019). Screening of fungi for potential application of self-healing concrete. Scientific Reports, 9, 2075

Mosyagin, A. V., Knauf, I. V., \& Zelenskaya, M. S. (2009). Deterioration of carbonate rocks used for archeological monuments in Tauric Chersonesos (Crimea). Studia Universitatis Babes-Bolyai, Geologia, 54(2), 13-16.

Nambiar, G. R., \& Raveendran, K. (2008). A checklist of marine fungi from Kerala State, India. American-Eurasian Journal of Botany, 1(3), 73-77.
Nambiar, G. R., \& Raveendran, K. (2015). Frequency of marine fungi on anima substrates along west coast of India. Current Research in Environmental and Applied Mycology, 5(4), 394-397.

Nambiar, G. R., Jaleel, C. A., \& Raveendran, K. (2008). A comparative account of backwater and brackish water marine mycoflora of North Malabar (Kerala) India. Comptes Rendus Biologies, 331(4), 294-297.

Orlova, T. I., Bulgakova, V. G., \& Polin, A. N. (2017). Vtorichnye metabolity morskih mikroorganizmov. II. Morskie griby $i$ ih sreda obitaniya [Secondary metabolites from marine microorganisms. II. Marine fungi and its environment]. Antibiotiki i Himioterapiya, 62(5-6), 68-76 (in Russian)

Pang, K.-L., Overy, D. P., Jones, E. B. G., Calado, M., Da, L., Burgaud, G., Walker, A. K., Johnson, J. A., Kerr, R. G., Cha, H.-J., \& Bills, G. F. (2016). 'Marine fungi' and 'marine-derived fungi' in natural product chemistry research: Toward a new consensual definition. Fungal Biology Reviews, 30(4), 163-175.

Pirkova, A. V. (2002). Porazhyonnost' chernomorskih ustric rakovinnoj boleznyu. Profilaktika i selekciya na ustojchivost' $\mathrm{k}$ zabolevaniyu [The infestation of Black Sea oysters with shell disease. Prevention and selection for disease resistance]. Rybnoe Hozyajstvo Ukrainy, 3(4), 45-47.

Pirkova, A. V., \& Dyomenko, D. P. (2008). Sluchai rakovinnoj bolezni u gigantskoj ustricy Crassostrea gigas (Bivalvia), kultiviruemoj v Chernom more [Cases of shell disease in the Pacific giant oyster Crassostrea gigas (Bivalvia), cultivated in the Black Sea]. Biologiya Morya, 34(5), 359-364 (in Russian).

Pivkin, M. V., Aleshko, S. A., Krasohin, V. B., \& Hudyakova, Y. V. (2006). Kompleksy gribov gubok u yuzhnogo poberezhya ostrova Sakhalin [Sponge fung complexes off the southern coast of Sakhalin Island]. Biologiya Morya, 32(4), 249-254.

Popova, T. A., Vlasov, O. Y., Zelenskaya, M. S., \& Panova, E. G. (2014). Bioobrastaniya granitnyh naberezhnyh Sankt-Peterburga [Biofouling of granite embankments in Saint Petersburg]. Vestnik of Saint Petersburg State University, $3(2), 30-40$.

Raghukumar, C. (Ed.) (2012). Biology of marine fungi. Springer-Verlag, Berlin, Heidelberg.

Richards, T. A., Jones, M. D. M., Leonard, G., \& Bas, D. (2012). Marine fungi: Their ecology and molecular diversity. Annual Review of Marine Science, 4, 495-522.

Sallenave-Namont, C., Pouchus, Y. F., Du Pont, T. R., Lassus, P., \& Verbist, J. F. (2000). Toxigenic saprophytic fungi in marine shellfish farming areas. Mycopathologia, 149, 21-25

Serova, T. A., \& Titova, Y. A. (2014). Mikobiota drevesiny istoricheskih pamyatnikov arhitektury Sankt-Peterburga i vozmozhnosti ee kontrolya s pomoshchyu fungicidov [Mycobiota of wood of historical architectural monuments of Saint Petersburg and the possibility of its control with fungicides]. Vestnik Zashchity Rastenij, 2, 33-37 (in Russian).

Svetlov, D. A., \& Kachalov, A. N. (2019). Mikrobiologicheskaya korroziya stroitel'nykh materialov [Microbiological corrosion of building materials]. Transportnye Sooruzheniya, 4(6), 1-19 (in Russian).

Tamayo-Cevallos, R. (2020). Lignicolous marine fungi in mangrove ecosystem State of knowledge and research perspective in Ecuador. Revista Ecuatoriana De Medicina Y Ciencias Biological, 41(2), 95-106.

Tibell, S., Tibell, L., Pang, K.-L., Calabon, M., \& Jones, E. B. G. (2020). Marine fungi of the Baltic Sea. Mycology, 11(1), 1-19.

Vlasov, D. Y. (2011). Mikroskopicheskie griby v ekstremal'nyh mestoobitaniyah: biologicheskoe raznoobrazie i sushchnost' vzaimodejstvij [Microscopic fungi in extreme locations: Biodiversity and the Nature of Interactions]. Biosfera, 3(4), 479-492 (in Russian).

Yakovleva, G., Sagadeev, E., Stroganov, V., Kozlova, O., Okunev, R., \& Ilinskaya, O. (2018). Metabolic activity of micromycetes affecting urban concrete constructions. The Scientific World Journal, 2018, 287.

Yarden, O. (2014). Fungal association with sessile marine invertebrates. Frontiers in Microbiology, 5, 228.

Zelenskaya, M. S., \& Vlasov, D. Y. (2001). Mikromicety kamenistogo substrata ostrovov Belogo moray [Micromycetes from stony substrates of islands in the White Sea ]. Mikologiya i Fitopatologiya, 35(2), 15-18.

Zelenskaya, M. S., \& Vlasov, D. Y. (2006). Mikromicety na pamyatnikah nacional'nogo zapovednika "Hersones Tavricheskij" (Krym) [Micromycetes on the monuments of the Tauric Chersonesos National Reserve (Crimea)]. Mikologiya i Fitopatologiya, 40(5), 370-376 (in Russian).

Zvereva, L. V., \& Vysockaya, M. A. (2005). Micelial'nye griby - associanty dvustvorchatyh mollyuskov iz zagryaznennyh biotopov Ussurijskogo zaliva Yaponskogo moray [Mycelial fungi - associates of bivalve mollusks from polluted biotopes of the Ussuri Bay of the Sea of Japan]. Biologiya Morya, 31(6), 443 446 (in Russian). 